Scientific journal

\section{PHYSICAL AND MATHEMATICAL EDUCATION}

Has been issued since 2013.

Науковий журнал

ФІЗИКО-МАТЕМАТИЧНА ОСВІТА

Видається з 2013.
ISSN 2413-158X (online)

ISSN 2413-1571 (print)

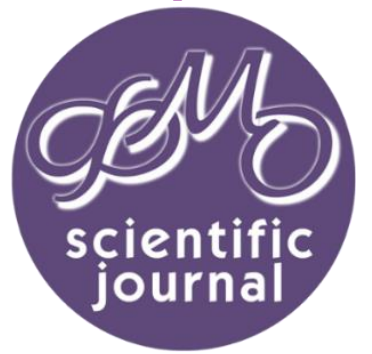

http://fmo-journal.fizmatsspu.sumy.ua/

Божкова В.В., Чикалова М.М. Підвищення кваліфікації педагогічних і науково-педагогічних працівників в Україні: проблеми і перспективи. Фізико-математична освіта. 2019. Випуск 2(20). С. 7-10.

Bozhkova V., Chykalova M. Professional Development Of Teaching And Research-Pedagogical Staff In Ukraine: Problems And Perspectives. Physical and Mathematical Education. 2019. Issue 2(20). P. 7-10.

DOI 10.31110/2413-1571-2019-020-2-001

UDC 378.046.4

Viktoriya Bozhkova

Makarenko Sumy State Pedagogical University, Ukraine vvbozhkova@gmail.com

ORCID: 0000-0002-1557-3819

Maryna Chykalova

Makarenko Sumy State Pedagogical University, Ukraine

anya_07@ukr.net

ORCID: 0000-0002-2660-3710

\title{
PROFESSIONAL DEVELOPMENT OF TEACHING AND RESEARCH-PEDAGOGICAL STAFF IN UKRAINE: PROBLEMS AND PERSPECTIVES
}

ABSTRACT

The problems and weaknesses of professional development of teaching and research-pedagogical staff system in Ukraine are analysed in the article. The needs of educational institutions in staff professional development are outlined. The principles of modernized system of professional improvement and perspectives of its innovative development are determined.

Formulation of the problem. The urgency of qualitative professional development of teaching and research-pedagogical staff and the accumulated contradictions of the traditional educational system determine the need to find ways and methods for significant modernization of the latter.

Materials and methods. Theoretical analysis of scientific sources, methods of comparison, synthesis, analysis, generalization are used. Results. The focus in the programs for professional development of teaching and research-pedagogical staff: the focus on the specifics of adults as consumers of educational services, including the physiological characteristics of different age groups of adults; the focus on the special needs of educational establishments while planning the contingent of advanced training; the focus on the use of computer technologies in the learning process; the focus on individual plans of teachers' professional development; the focus on ensuring mutual exchange of experience in internship programs.

Conclusions. The outlined principles allow to determine both the vector of the system of further training movement as a whole and the opportunities for each employee personally. The common forms and types of further training of teaching and researchpedagogical staff have been investigated, which allows distinguishing their advantages and necessary accents of professional development programs in general.

KEY WORDS: professional development, teaching and research-pedagogical staff, programs, electronic educational web-resources.

\section{INTRODUCTION}

Problem formulation. Acceleration of information and technological changes taking place in the modern globalized space promotes formation of new requirements to the processes of specialists' professional training. Those educational institutions that both implement the results of scientific and technical development, and are proactive implementing fundamentally new tactical decisions become successful on the educational market. The experience of leading world universities (from Oxford, Harvard, Massachusetts, Michigan, Stanford, etc.) with about a third of the total number of students studying through a distance learning strategy is noteworthy.

At the same time the teachers themselves have to realize the purpose of qualitative training of competitive specialists through specific tasks, content, methods, means and results of work at the level of each academic discipline and the training process as a whole. Accordingly, the challenges of our time (Androshchuk, 2009) with regard to innovations in the educational system are primarily related to training, retraining and professional development of teaching and research-pedagogical staff. Consequently, the urgency of studying the problems of professional development of teaching and research-pedagogical staff in Ukraine leaves no room for doubt. 
The urgency of qualitative professional development of teaching and research-pedagogical staff and the accumulated contradictions of the traditional educational system determine the need to find ways and methods for significant modernization of the latter.

The analysis of recent research and publications. According to the Article 59 of the Law of Ukraine «On Education» (No. 2145-VIII of September 5, 2017) the professional development of teaching and research-pedagogical staff involves constant selfeducation, participation in professional improvement programs and any other types and forms of career development. Professional development can be carried out in different forms such as educational training, internships, participation in certification programs, trainings, seminars, seminar-workshops, seminar-meetings, training-seminars, webinars, master-classes etc. as well as in various forms like institutional, dual, in the workplace and etc.) (Law of Ukraine, 2017).

The quality of career development and further updating the educational process in educational institutions depends on their diversity, accessibility and scientific quality.

A number of scientific works are devoted to the study of problems of professional development of teaching and researchpedagogical staff. In particular, Larysa Olifira considered the theoretical basis of the career development based on the accumulation system (Olifira, 2018), William Conaway - the definition of andragogical principles for the training of different age groups adults (Conaway, 2009), Olga Agapova - methods of activation and motivation of the people belonging to the older age group (Agapova, 2013), Robert Boits (Boits, 2005) and Pavlo Danzanov (Danzanov, 2012) - contradictions in the system of teachers' professional development, Oleksandr Novikov - a theoretical model of the activity approach in the learning processes (Novikov, 2008) etc.

However, from our point of view this problem remains not sufficiently developed in the context of strategic challenges faced the educational system in Ukraine.

The purpose of this study is both to identify the main problems in the system of professional development of teaching and research-pedagogical staff and to determine the main perspectives and directions for its improvement.

\section{MATERIALS AND METHODS.}

Theoretical analysis of scientific sources, methods of comparison, synthesis, analysis, generalization are used.

\section{RESULTS AND DISCUSSION}

By reference to the practice of professional development of teaching staff taking place in Ukraine at least once every five years it can be assumed that about $20 \%$ of the higher educational institutions personnel should attend a refresh course per year. This is a quite large number, and the current realities of a higher school, as a rule, do not allow providing such a number of employees with any reducing of annual academic load. Therefore, the participants put forward very high requirements to the professional development programs (both in terms of performance and on time costs). In practice, the percentage of staff participation in advanced training programs may be even higher due to the special needs of an educational institution.

On the other hand, the professional development system has accumulated a great deal of contradictions for nearly its 100 years history. Along with the dissemination of electronic educational Web resources, there is the preservation of extremely inflexible mechanisms of work (based mainly on lecture forms of learning); while obviously necessary is open and dynamic system.

For example, the concept of open educational resources Open Course Ware (being implemented by the Massachusetts Institute of Technology since 2002) provides any user of the global network with the opportunities to diverse, constantly updated scientific, educational and methodological materials that are freely available and can be freely used.

The following principles should be based on the modernized system of professional development of teaching and research-pedagogical workers in Ukraine:

- scientific and quality approach (will provide continuous updating of professional knowledge);

- diversity (the variability of the programs will enable to design their own trajectory of professional development);

- integrity, continuity and continuance (availability of programs in accordance with qualification requirements and tasks; facilitates lifelong learning);

- academic honesty and personal responsibility;

- academic freedom (including the choice of types, forms and pace of education, an educational program, an educational institution and other subjects of educational activity etc.);

- integration into the international educational and scientific space (including co-relations with world and national history, culture and traditions).

Accepted pedagogical principles define both the vector of the professional development system movement in general and opportunities for each employee personally.

The effectiveness of the career development programs is to acquire new knowledge, skills and know-how, recognized by educational institutions, as well as in specific results that meet the goals and objectives of research and pedagogical activities of a high professional level and can be introduced into the activities of pedagogical and research-pedagogical workers and relevant structural subdivisions.

The next factor that, in our opinion, requires special attention in the processes of advanced training, are the age-old features of the participants. There is not enough general targeting for the «adult» audience, it is necessary to take into account the physiological characteristics of different age groups.

For example, the Wendy Conaway's study highlighted the differences between adult age groups of the three levels:

18-25 - «those who becomes adults» (from English Emerging adults);

26-39 - "young Adults» (from English Young adults);

40-59 - «mature adults» (from English Mature adults) (Conaway, W. 2009).

Our experience suggests that these age categories behave differently in relation to the acquisition of advanced training programs. The structure of the target audience is further complicated taking into account the different status of teaching and research- pedagogical workers (from assistant to professor). Possible solution of this optimization problem (resources provided 
the quality of the process) is to implement the principle of personal responsibility of the pedagogical and research-pedagogical worker for the improvement of professional skills, planning the programs of professional development by themselves.

The new Law "On Education» (Law of Ukraine, 2017) not only eliminated the state monopoly on the professional development of teachers, but also outlined broad opportunities for educators to improve their qualifications and pedagogical skills. Now every teacher can plan his/her own career development both in content and methods, and in types and forms.

One of the modern forms of professional development that has become widespread in the leading countries of the world (in line with the recommendations of the European Parliament and the Council of Europe «Adoption of the European Qualifications Framework for Lifelong Learning», as well as «European Principles for the Examination of Non-formal and Informal Learning» and other documents of the Bologna Process), is the so-called «accumulation system». It includes the accounting of the most significant results of professional development by benchmarks (for example, internships in research and educational organizations (including abroad), preparation of the student-winner of an Olympiad or competition of scientific works, publication of an article in academic journals, which are referenced by the Scopus database, obtaining an author's copyright document etc.).

One of the possible results that are taken into account by this system is the certificate of a successful completion of online courses of professional development from experienced teachers of the best universities in the world (Table 1). Electronic educational Web-resources can also be useful in preparing teaching and research-pedagogical staff for lessons.

Basic Online Learning Services

(generalized according to the materials (The main online services for training, 2019))

\begin{tabular}{|c|c|c|}
\hline $\begin{array}{l}\text { On-line } \\
\text { services }\end{array}$ & Specifics & $\begin{array}{l}\text { Main target } \\
\text { group }\end{array}$ \\
\hline Prometheus & $\begin{array}{l}\text { Public project of mass open free online-courses for professional development of educators } \\
\text { from teaching staff of the best universities in the world and experienced Ukrainian educators. } \\
\text { Provides a free opportunity for universities, leading lecturers and leading companies to } \\
\text { publish and distribute the courses on this platform. Each course consists of video lectures, } \\
\text { interactive tasks, as well as a forum where students can ask the teacher any questions and } \\
\text { communicate with each other. The students receive an electronic certificate on the basis of } \\
\text { the successful results of the course that confirms the acquired knowledge. }\end{array}$ & Teaching staff \\
\hline Coursera & $\begin{array}{l}\text { Offers hundreds of free online-courses in various disciplines and in case of successful results } \\
\text { of the course a certificate is issued. Collaborates with foreign universities all over the world } \\
\text { to teach the courses of these educational institutions online. Courses are free but paid } \\
\text { certificates for individual courses are foreseen too. During the training, the student has to } \\
\text { view video-lectures sent to him/her weekly, read the recommended articles and do prep. } \\
\text { Some courses have Ukrainian subtitles. }\end{array}$ & Students \\
\hline $\begin{array}{l}\text { Khan } \\
\text { Academy }\end{array}$ & $\begin{array}{l}\text { Educational organization (since 2006) to provide quality education to everyone and } \\
\text { everywhere. The site contains several thousand free micro-lectures in mathematics, physics, } \\
\text { chemistry, history, finance, economics, biology, art and computer science etc. All courses are } \\
\text { divided into lessons with the ability to view regardless of the course chosen. The project is } \\
\text { supported by donations. }\end{array}$ & Schoolchildren \\
\hline Udacity & $\begin{array}{l}\text { Most courses are of technical orientation. Each course has several lessons that contain short } \\
\text { videos. At the end of the lesson there is a task to test the learned material. On average, the } \\
\text { course lasts up to } 2 \text { months, and it takes approximately } 6 \text { hours to study for each week }\end{array}$ & $\begin{array}{l}\text { Students and } \\
\text { teaching staff }\end{array}$ \\
\hline$e d X$ & $\begin{array}{l}\text { A joint project of the Massachusetts University of Technology and Harvard University. More } \\
\text { than } 200 \text { universities from all over the world provide their materials here. The courses are } \\
\text { free, but the certificate is paid. }\end{array}$ & Students \\
\hline iTunes $U$ & $\begin{array}{l}\text { The platform for Apple devices. The list of the proposed subjects is very large, as well as the } \\
\text { list of educational institutions providing lectures. Often there are auxiliary files in the lesson, } \\
\text { which explain some aspects of the lectures, or give examples of the lesson learned. }\end{array}$ & $\begin{array}{l}\text { Students and } \\
\text { teaching staff }\end{array}$ \\
\hline Udemy & $\begin{array}{l}\text { The largest selection of both free and paid courses. New courses are added to the site } \\
\text { monthly. The training materials are presented in the form of videos, audios, presentations } \\
\text { and texts. There is an opportunity for organizations to create their own training projects for } \\
\text { corporate learning. }\end{array}$ & $\begin{array}{l}\text { Teaching staff, } \\
\text { entrepreneurs } \\
\text { and students }\end{array}$ \\
\hline
\end{tabular}

The approach based on the "accumulation system» to professional development of the teachers who are quite active in their own career development and have achieved the highest results allows to customize the learning process and get maximum results at minimal costs that is, it can provide the highest efficiency.

Thus, the system of professional development includes the processes of career improvement planning by the lecturer $\mathrm{him} /$ herself and recognizes the results of the implementation of these plans.

On the other hand, there are specific needs of educational institutions that can be realized through the following possibilities:

- new specialties opening;

- new information and computer technologies introduction;

- specialized services (for example, teaching in a foreign language) expansion;

- intensification of international activities etc.

The most popular type of professional development among the teaching staff is an internship that provides wide opportunities for mutual exchange of experience and fully corresponds to the specific needs of educational institutions (Training of pedagogical staff,2019). 
Summarizing the abovementioned we will focus on the programs for professional development of teaching and researchpedagogical staff:

- the focus on the specifics of adults as consumers of educational services, including the physiological characteristics of different age groups of adults;

- the focus on the special needs of educational establishments while planning the contingent of advanced training;

- the focus on the use of computer technologies in the learning process;

- the focus on individual plans of teachers' professional development;

- the focus on ensuring mutual exchange of experience in internship programs.

\section{CONCLUSIONS}

Thus, according to the results of the study, the following conclusions can be drawn:

1. The needs of educational establishments in professional development of teaching and research-pedagogical staff are determined according to the strategic objectives of the innovative development of the educational system as a whole.

2. The outlined principles of the modernized system of the professional development of teaching and researchpedagogical staff allow defining both the vector of the system movement as a whole, and opportunities for each employee personally.

3. The spent resources optimization under the condition of qualitative process of professional development provision is possible by the "accumulation system» of accounting of the most significant results of professional development.

4. The programs of the professional development of teaching and research-pedagogical staff should take into account the special needs of educational institutions regarding the qualification of personnel, the specific features of different age groups training, as well as to be based on the use of computer technologies in the learning process.

Further research will focus on systematization, detailed elaboration of world experience concerning progressive forms and types of professional development of teaching and research-pedagogical staff.

\section{References}

1. Agapova, O. (2013). Methods of activating and motivating older people to participate in society: a practical course. Retrieved from http://dvv-international.by/en/publications/methods-of-activatingthe-elderly/ [in Ukrainian]

2. Androshchuk, G.O. Zhilyaev, I.B. Chizhevsky, B.G. Shevchenko, MM. (2009). The strategy of innovative development of Ukraine for 2010-2020 in the face of global challenges, K .: Parliamentary view, 632.

3. Boits, R. (2005). Tips for Beginner Teachers, K .: Educational and Methodological Center "Consortium for Improvement of Management Education in Ukraine", 448 [in Ukrainian].

4. Conaway, W. (2009). Andragogy: Does One Size Fit All? A Study to Determine the Applicability of Andragogical Principles to Adult Learners of All Ages, Walden University, 135.

5. Danzanov, P.G. (2012). Improving teacher qualification. Analysis of contradictions, Journal of the head of education management, № 5, 65-70 [In Russian].

6. Law of Ukraine "On Education" № 2145-VIII of September 5, 2017 Retrieved from http://en.osvita.ua/legislation/law/2231/list/2/ [in Ukrainian].

7. Novikov, A.M. (2008). Post-industrial education, M .: Egves, 132 [In Russian].

8. Olifira, L.M. (2018). Improvement of qualification of managerial, pedagogical and scientific-pedagogical workers on the cumulative system: the answer to the challenges of the present, Journal «ScienceRise: Pedagogical Education», №4 (24), 4347. [in Ukrainian]

9. The main online services for training (2019). Retrieved from https://inspired.com/ideas/services/7-online-courses/ [in Ukrainian].

10. Training of pedagogical staff (2019). Website of the Ministry of Education and Science of Ukraine. Retrieved from https://mon.gov.ua/en/osvita/profesijno-tehnichna-osvita/pidvishennya-kvalifikaciyi-pedagogichnih-pracivnikiv [in Ukrainian].

\section{ПІДВИЩЕННЯ КВАЛІФІКАЦІЇ ПЕДАГОГІЧНИХ І НАУКОВО-ПЕДАГОГІЧНИХ ПРАЦІВНИКІВ В УКРАЇНІ: ПРОБЛЕМИ І ПЕРСПЕКТИВИ \\ В.В. Божкова, М.М. Чикалово}

Сумський державний педагогічний університет імені А.С. Макаренка, Україна

Анотація. У статті проаналізовано проблеми та недоліки системи підвищення кваліфікації педагогічних і науково-педагогічних працівників в Україні; окреслено потреби закладів освіти в підвищенні кваліфікації кадрів; визначено принципи модернізованої системи підвищення кваліфікації та перспективи ії інноваційного розвитку.

Формулювання проблеми. Актуальність якісного підвищення кваліфікації педагогічних і науково-педагогічних працівників інакопичені протиріччя традиційної системи освіти визначають необхідність пошуку шляхів і методів суттєвої модернізації останньої.

Матеріали і методи. Використовується теоретичний аналіз наукових джерел, методи порівняння, синтезу, аналізу, узагальнення.

Результати. Основні акценти в програмах підвищення квалірікації педагогічних та науково-педагогічних кадрів мають бути такі: акцент специфіки дорослих як споживачів освітніх послуг, в тому числі урахування фізіологічних особливостей різних вікових груп дорослих; акцент особливих потрб закладів освіти при плануванні контингенту підвищення кваліфікації; акцент використання комп'ютерних технологій в процесі навчання; акцент індивідуальних планів підвищення кваліфікації педагогів; акцент забезпечення взаємного обміну досвідом в програмах стажувань.

Висновки. Окреслені принципи дозволяють визначати як вектор руху системи підвищення квалірікації в цілому, так і можливості для кожного працівника персонально. Дослідження поширених на практиці форм і видів підвищення кваліфікації педагогічних і науково-педагогічних працівників дозволило виокремити їх переваги та необхідні акценти програм підвищення квалірікації в цілому.

Ключові слова: підвищення кваліфікації, педагогічні й науково-педагогічні прачівники, програми, електронні освітні веб-ресурси. 